\title{
Re-examining millet impressions in Usatovo clay materials from NW Black Sea region, Ukraine
}

\author{
Ting $\mathrm{An}^{1,2}$ (D) Galyna Pashkevich ${ }^{3} \cdot$ Martin Jones $^{2}$ \\ Received: 27 March 2018 / Accepted: 20 September 2018 / Published online: 17 November 2018 \\ (C) The Author(s) 2018
}

\begin{abstract}
The past decade has witnessed debates on the coherence of trans-Eurasian interaction into a particular episode, either the movement of 'cultural package' circulating around the 2nd millennium BC or a process more dispersed in time and space. Of particular are the very early published records of broomcorn and foxtail millet in Western Eurasia. Records of charred millet in Europe pre-dating the fifth millennium $\mathrm{BC}$ have been called into question using direct radiocarbon dating. The other component of the early millet evidence, impressions in ceramics, consequently becomes critical. In this article, we re-examine a key subassemblage of early millet impressions in Europe, specifically those found in Usatovo materials from NW Black Sea Region (Ukraine) as a case study to assess the authenticity of such identifications. We conclude that SEM examination of Usatovo samples reveals insufficient evidence for a secure identification of Panicum miliaceum although the void dimensions may be plausible. We also draw attention to features that could usefully be sought when examining impressions in the future.
\end{abstract}

Keywords Usatovo $\cdot$ Millet impression $\cdot$ Casting $\cdot$ SEM examination

\section{Introduction}

West and East Eurasia have interacted since prehistoric times. By the first millennium $\mathrm{BC}$, the evidence of trans-Eurasian exchange includes material culture and texts (the historical Silk Road). Archaeologists through time have been looking for traces before the first millennium $\mathrm{BC}$, for example through studies of metallurgy, and have managed to take the interaction into the second millennium BC. However, if we go earlier, there are many other claims of substantially early interaction between communities to the west of Altai and those to the east of Altai. Some claims are contentious while others are not. Among all claims, of particular interest is the spread of broomcorn and foxtail millet across Eurasia. A significant number of Panicum miliaceum records are from pre-5000

Ting An

anting0508@gmail.com

1 School of Humanities, Zhejiang University, Hangzhou, China

2 Department of Archaeology, University of Cambridge, Cambridge, UK

3 Retired from Institute of Geological Sciences, National Academy of Sciences of Ukraine, Kiev, Ukraine
BC sites in Europe (Hunt et al. 2008). Such early dates have been called into question by direct dating evidence of charred broomcorn millets found in Europe, which demonstrates grains as small as the millets could move downwards into earlier stratigraphic levels (Motuzaite-Matuzeviciute et al. 2013). Beyond charred grain, early European millet dates also come from grain impressions in ceramics, which are the focus of this paper. Here, we assess the robustness of the evidence from grain impressions for a pre second millennium BC spread of millet from China to Europe.

Essentially, the current paper seeks to contribute to the debate over whether there was an even horizon where crops and metallurgy circulated together during the second millennium $\mathrm{BC}$, or rather, if the spread of crops significantly predated metallurgy interchange by several millennia, in the case of millet taxa. The significance of it is not only about chronology, but moreover relates to the larger debate on the driving force of prehistoric Eurasian exchange, whether it is 'bottom-up' (arising among farmers and initially traced by crop movement) or 'top-down' (elite-led, and initially traced by high status material culture).

Our approach to re-identification addresses the following two questions:

First, how confidently can impressions that fall in a selected size range and formed in a certain shape be categorised as 
millet impressions? Second, can we observe the surface features on the impressions that may be regarded as taxonomically diagnostic?

According to two comprehensive reviews of early millet impressions from Europe (Hunt et al. 2008; An 2018), all findings, with one exception from Bulgaria, are concentrated in Moldova and Ukraine. Millet impressions and/or macrofossils are reported from nearly 100 settlements in Moldova and Ukraine (e.g. Kuzminova 1990, 1991; Kuzminova and Petrenko 1989; Yanushevich 1978, 1989). According to Yanushevich (1989), Panicum sp. first appeared in an early Neolithic site of Bug-Dniester Culture, though the identification is marked as tentative. By the middle Neolithic period, particularly on the site of Dantcheny I (LBK Culture) in Dniester-Prut Region, as many as 59 impressions of Panicum miliaceum are reported (Yanushevich 1989). By the Eneolithic (the period of Tripolye Culture and Gumelnitsa Culture), there are individual findings of both impressions and grains of Panicum miliaceum (ibid).

In the Early Bronze Age, Usatovo Culture is commonly associated with millet agriculture. Kuzminova reports numerous millet impressions on 70 fired clay figurines in Usatovo Culture assemblages from sites of Usatovo-Bolsoy Kuyalnik (also called as 'Usatovo') and Mayaki (Kuzminova and Petrenko 1989). The authors argue that Panicum miliaceum was the main cultivated plant in Usatovo agriculture, suggesting that millet became prevalent during the Tripolye CII period (ibid. p.119). Elsewhere (Kuzminova 1990), Kuzminova reports that 'in a tableware vessel from a burial context, soil was found with some remains of charred millet porridge' (ibid. p.260). In the original Russian text, it is unclear whether the author refers to Panicum sp. or the specific species of Panicum miliaceum. Whether it is Panicum miliaceum or Panicum miliaceum subsp. ruderale is not addressed.

Impressions identified as Panicum sp. clearly recur in Ukraine and Moldova. However, there are few images of them in earlier publications. A number of authors draw attention to the possible confusion between impressions of Panicum miliaceum and those of, for example, Setaria sp., Echinochloa sp. and wild Panicum (Motuzaite-Matuzeviciute et al. 2013; Stevens et al. 2016). A concern is shared among these authors that the identification criteria in previous studies are limited to the shape and size of the 'voids' such as in (Yanushevich 1976: 153). Because of the great variation in size, Motuzaite-Matuzeviciute et al. (2013) suggests also using scutellum details. However, this would only assist in the case of dehusked grains.

It is often difficult to track down previous published records for re-examination, as previous authors have rarely separated out the particular pieces with millet impressions from the large quantities of materials where these were selected. Here, we conduct fresh examination of Usatovo materials in order to re-assess previous identifications. Kuzminova did not separate out the 70 pieces of figurine fragments on which she reported to have found millet impressions (Kuzminova and Petrenko 1989), but the particular series of storage units she worked on are available to us for re-examination. Consequently, among all Usatovo materials at Odessa Archaeological Museum, we chose 20 storage units including all of those examined by Kuzminova in the 1980s on which she reported to have found Panicum miliaceum impressions. Dr. Petrenko, who co-authored the article with Kuzminova, assisted with our reassessment in this paper.

Usatovo is often considered to be a local variant of the CII phase of Tripolye Culture (Mallory and Adams 1997; Ivanova 2013; Weninger and Harper 2015; Diachenko and Harper 2016), while Petrenko and Kaiser (2011) treat it as a distinct culture in its own right. The main distribution of Usatovo sites (seen in Fig. 1) is concentrated in the northwest area of the Black Sea.

Material culture finds in Usatovo culture are mostly from burial mounds (kurgans). They comprise painted ceramics (510\%) (Ivanova 2013), shell-tempered coarse wares, figurines and arsenical bronze etc. (Mallory and Adams 1997).

In terms of the absolute chronology of Usatovo Culture, all 42 radiocarbon dates from Usatovo sites are summarised by Petrenko and Kaiser (2011). These authors place Usatovo Culture between the second half of fourth and the beginning of third millennium BC, around 3500-2900 BC. However, 13 of the 42 dates fall in the subsequent millennium (as late as $1760 \mathrm{BC}$ ). These later dates are regarded to be 'most doubtful and unverified' (original text in Russian) (ibid) and have been excluded and attributed to the reservoir effect (ibid).

\section{Methodology}

Crop impressions are often studied using the casts of them examined under optical microscope, and then, if necessary, further analysed with SEM.

For impression casting materials, the two most popular current methods use plasticine and silicone compound. Plasticine casting is more straightforward. However, silicone casts are more durable, lending themselves to transport between institutions. The silicone compound casting agent consists of two parts, a base and a catalyst (Fuller and Macdonald 2007). These are mixed together and then quickly applied to the voids using a brush.

In the current project, we first made two copies using both plasticine and silicone compound (brand name, Speedex) to establish which compound captured surface details with greater precision. We found that plasticine was capable of picking up surface detail, even from a dirty impression. However, silicone only formed a viable cast when the dirt had been removed a few times, and even then, it often missed some of the surface detail acquired by plasticine. We ended up with multiple silicone casts of the same void, yet still found it 
Fig. 1 Location of Usatovo group/culture in the northwest of Black Sea

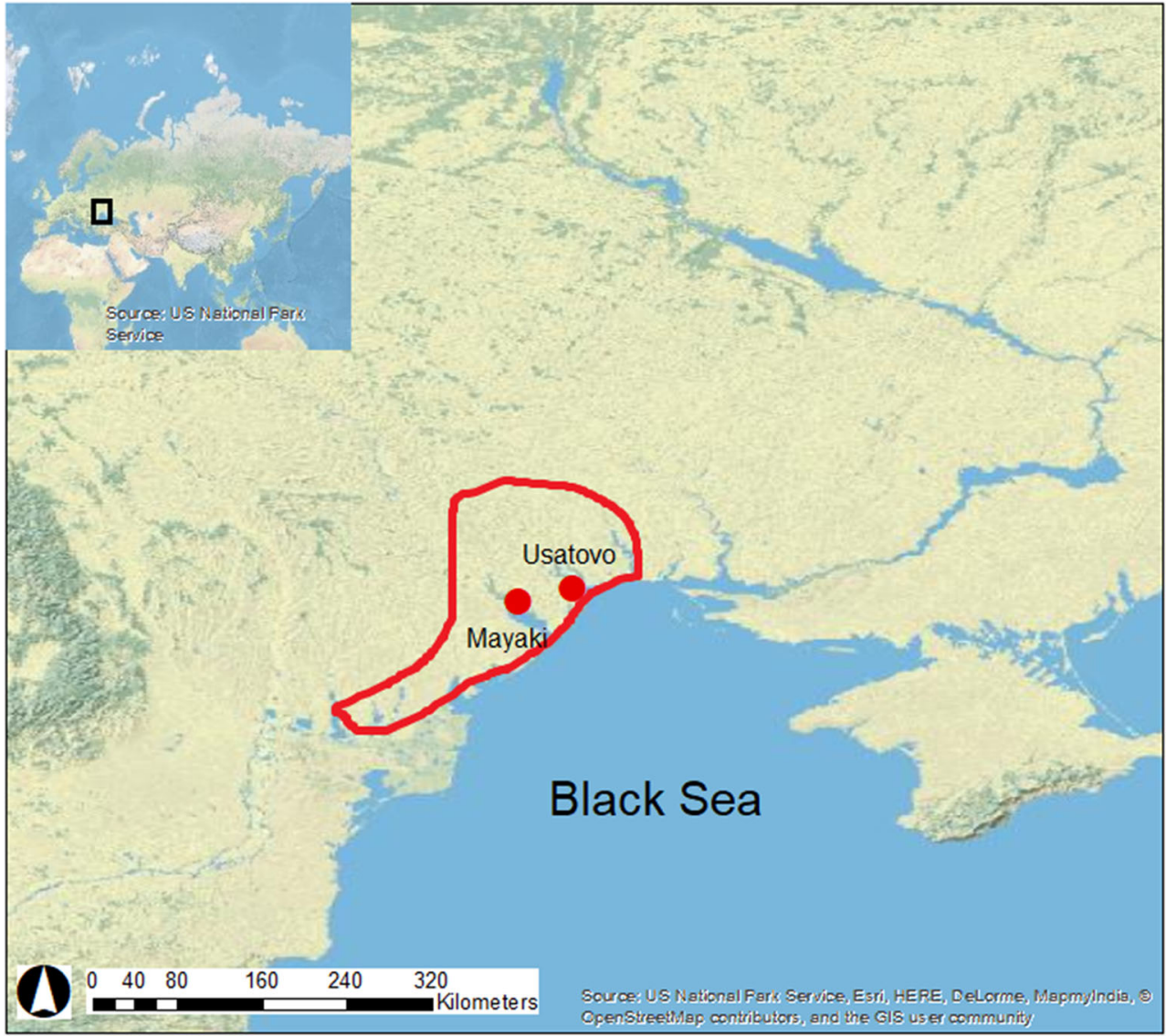

difficult to obtain a complete cast as many of them broke down when removed from the ceramic. Having compared our casts of plasticine and silicone, we concluded that plasticine casts were capable of capturing greater detail. We therefore made casts of all voids using plasticine instead of silicone compound.

East cast was first examined with the naked eye. Then, casts of the right dimensions were examined by optical microscope in Ukraine for best matches of shape and size. Grain impressions correspond to the size and shape of the respective soaked and inflated grains due to moist clay, which would later shrink again by approximately 5-8\% during the firing and sunbake process (Renfrew 1973; Magid 1989). By measuring and comparing the sizes of Panicum miliaceum grains in two different forms, Renfrew (1973) reports that grain impressions are slightly longer than the equivalent grain in carbonised form. However, both fall within the overall size variation of Panicum miliaceum (Motuzaite-Matuzeviciute 2012). Specifically, the breadth range of millet grain can be as much as $1.0-2.0 \mathrm{~mm}$ and the range in length is $1.2-3.0 \mathrm{~mm}$ (ibid). In other words, grain size can vary by an order of magnitude.

Turning to grain shape, the identification criteria for Panicum miliaceum grain include one end being acute and the other blunt (Fuller 2006; Nesbitt and Summers 1988).
We compared the SEM images of our casts of Panicum miliaceum impressions from Usatovo materials with references of Panicum miliaceum impressions. We refer to SEM images of millet impressions of both husked and dehusked grain from a simulation exercise (An 2018). The simulated impressions are made on fine clay, fired at modern kiln and cast using silicone compound.

In the case of impressions of husked millet, the specific features that are compared comprise shape, size, lemma, palea and husk surface patterns. In the case of dehusked grain, the identifying features comprise size, shape and scutellum details. The husk surface of Panicum miliaceum grain is smooth and glossy, which is distinctive from that of Setaria sp. and Echinochloa sp. (Fuller 2006, Nesbitt and Summers 1988). Hence, it is considered as an additional identification criterion beyond the size and shape of the millet grain.

The form of impressions may be altered by varying firing and clay conditions. Another factor which may have affected the result is different casting materials, i.e., Usatovo samples cast with plasticine, while the simulated ones with silicone compound. Also, Usatovo samples are in coarse clay while simulated impressions are made in fine clay. These issues are not explored in the current study. 
Table 1 Context information of Usatovo records of plants impressions in the current study. The best matches in terms of shape and dimension are observed by a combination of naked eye and low power optical microscope. As these are the best matches, rather than proposed definitive identifications, we have dispensed with the 'cf.' notation, which formally might be applied to all records. On the left column, the letters of a, b, c etc. are used to differentiate findings from the same sample unit (i.e. box/bag). The 'unidentified grass' here includes but is not limited to Poa, Digitaria, Nardus and Phleum sp.

\begin{tabular}{|c|c|c|c|c|c|c|}
\hline $\begin{array}{l}\text { Sample } \\
\text { unit }\end{array}$ & Nature of materials & Site name & Information on the label & $\begin{array}{l}\text { Best fit } \\
\text { identification }\end{array}$ & $\begin{array}{l}\text { Location of } \\
\text { impressions }\end{array}$ & $\begin{array}{l}\text { Number of } \\
\text { impressions }\end{array}$ \\
\hline 1 & Anthropomorphic figurines & $\begin{array}{l}\text { Burial context of } \\
\text { Usatovo site }\end{array}$ & & & & \\
\hline $2 \mathrm{a}$ & Clay daub & $\begin{array}{l}\text { Ditch at hillfort } \\
\text { Mayaki }\end{array}$ & 1986 & $\begin{array}{l}\text { Hordeum } \\
\text { vulgare }\end{array}$ & & 5 \\
\hline $2 b$ & & & & $\begin{array}{l}\text { Triticum } \\
\quad \text { dicoccon }\end{array}$ & & 2 \\
\hline $2 \mathrm{c}$ & & & & $\begin{array}{l}\text { Panicum } \\
\text { miliaceum }\end{array}$ & & 1 \\
\hline $2 \mathrm{~d}$ & & & & Poa sp & & 1 \\
\hline 3 & 67 ceramic fragments & $\begin{array}{l}\text { Hillfort and burial } \\
\text { context of Usatovo }\end{array}$ & $\begin{array}{l}\text { Fragment from square no. } 20 \text {, } \\
\text { excavation И }\end{array}$ & Prunus sp. & & 1 \\
\hline $4 a$ & 195 fragments of painted ceramics. & Hillfort of Usatovo & Fragment from square no. 4 & $\begin{array}{l}\text { Hordeum } \\
\quad \text { vulgare var } \\
\text { coeleste }\end{array}$ & & 1 \\
\hline $4 b$ & & & Fragment No. 4048 & $\begin{array}{l}\text { Unidentified } \\
\text { grass }\end{array}$ & & 1 \\
\hline 5 & $\begin{array}{l}135 \text { sherds of vessel walls, } 39 \text { sherds of } \\
\text { painted ceramic and } 14 \text { sherds of vessel } \\
\text { bottoms }\end{array}$ & $\begin{array}{l}\text { Tombs No.1-8; no } \\
\text { other site info }\end{array}$ & $\begin{array}{l}\text { Fragment A-10270, square 2, } \\
1929 \text { year. }\end{array}$ & $\begin{array}{l}\text { Triticum } \\
\quad \text { dicoccon }\end{array}$ & & 1 \\
\hline 6 & 217 sherds of vessel walls. & Hillfort Usatovo & $\begin{array}{l}\text { Fragment no. } 69 \text { from square } \\
29 \text {, excavation И, } 1940 \text { year }\end{array}$ & $\begin{array}{l}\text { Panicum } \\
\quad \text { miliaceum }\end{array}$ & & 1 \\
\hline 7 & 116 sherds of vessel bottoms & Hillfort Usatovo & & & & \\
\hline $8 \mathrm{a}$ & 87 sherds of painted pottery & Hillfort Usatovo & $\begin{array}{l}\text { Fragment } 1767 \text {, excavation } Q \text {, } \\
1929 \text { year }\end{array}$ & $\begin{array}{l}\text { Hordeum } \\
\text { vulgare }\end{array}$ & & 1 \\
\hline $8 b$ & & Hillfort Usatovo & $\begin{array}{l}\text { Fragment } 3521 \text {, excavation И, } \\
1940 \text { year }\end{array}$ & $\begin{array}{l}\text { Hordeum } \\
\quad \text { vulgare }\end{array}$ & & 1 \\
\hline $8 \mathrm{c}$ & & Hillfort Usatovo & Fragment 5020, 1932 year & Cannabis sp. & & 1 \\
\hline $8 \mathrm{~d}$ & & Hillfort Usatovo & $\begin{array}{l}\text { Fragment } 8939,1940 \text { year, } \\
\text { excavation B }\end{array}$ & Cannabis sp. & & 1 \\
\hline $8 \mathrm{e}$ & & Hillfort Usatovo & $\begin{array}{l}\text { Fragment } 8288,1929 \text { year, } \\
\text { corridor B }\end{array}$ & $\begin{array}{l}\text { Unidentified } \\
\text { grass }\end{array}$ & & 1 \\
\hline $9 \mathrm{a}$ & 80 sherds of vessel bottoms & Hillfort Usatovo & $\begin{array}{l}\text { Fragment 7199, excavation } \\
\quad 1927,1932-1933\end{array}$ & $\begin{array}{l}\text { Hordeum } \\
\quad \text { vulgare }\end{array}$ & $\begin{array}{l}\text { Outside } \\
\text { surface }\end{array}$ & 1 \\
\hline $9 b$ & & Hillfort Usatovo & $\begin{array}{l}\text { Fragment } 7224 \text {, excavation } \mathrm{T} \text {, } \\
\text { square } 35\end{array}$ & $\begin{array}{l}\text { Hordeum } \\
\text { vulgare }\end{array}$ & $\begin{array}{l}\text { Outside } \\
\quad \text { surface }\end{array}$ & 1 \\
\hline $9 \mathrm{c}$ & & Hillfort Usatovo & Fragment 9896, 1927 & $\begin{array}{l}\text { Panicum } \\
\quad \text { miliaceum }\end{array}$ & $\begin{array}{l}\text { Outside } \\
\text { surface }\end{array}$ & 1 \\
\hline 10 & 328 sherds of painted bowls & Hillfort Usatovo & Fragment 4654, 1932 and 1933 & $\begin{array}{l}\text { Hordeum } \\
\text { vulgare }\end{array}$ & $\begin{array}{l}\text { Inside } \\
\text { surface }\end{array}$ & 1 \\
\hline $11 \mathrm{a}$ & 15 packages of clay daub & $\begin{array}{l}\text { ditch in the settlement } \\
\text { context of Mayaki } \\
\text { site }\end{array}$ & & $\begin{array}{l}\text { Hordeum } \\
\text { vulgare }\end{array}$ & & 12 \\
\hline $11 b$ & & $\begin{array}{l}\text { ditch in the settlement } \\
\text { context of Mayaki } \\
\text { site }\end{array}$ & & $\begin{array}{l}\text { Triticum } \\
\quad \text { dicoccon }\end{array}$ & & 1 \\
\hline $11 \mathrm{c}$ & & $\begin{array}{l}\text { ditch in the settlement } \\
\text { context of Mayaki } \\
\text { site }\end{array}$ & & $\begin{array}{l}\text { Tricicum } \\
\quad \text { aestivums. L }\end{array}$ & & 1 \\
\hline $11 d$ & & $\begin{array}{l}\text { ditch in the settlement } \\
\text { context of Mayaki } \\
\text { site }\end{array}$ & & Bromus sp. & & 1 \\
\hline $11 \mathrm{e}$ & & $\begin{array}{l}\text { ditch in the settlement } \\
\text { context of Mayaki } \\
\text { site }\end{array}$ & & Poa sp. & & 1 \\
\hline $11 \mathrm{f}$ & & $\begin{array}{l}\text { ditch in the settlement } \\
\text { context of Mayaki } \\
\text { site }\end{array}$ & & $\begin{array}{l}\text { Unidentified } \\
\text { grass }\end{array}$ & & 2 \\
\hline $12 \mathrm{a}$ & 456 pottery sherds & Hillfort Mayaki & $\begin{array}{l}\text { Excavation }(2005,2006 \text { and } \\
\text { 2013) }\end{array}$ & Triticum sp & & 1 \\
\hline $12 \mathrm{~b}$ & & Hillfort Mayaki & & & & 1 \\
\hline
\end{tabular}


Table 1 (continued)

\begin{tabular}{|c|c|c|c|c|c|c|}
\hline $\begin{array}{l}\text { Sample } \\
\text { unit }\end{array}$ & Nature of materials & Site name & Information on the label & $\begin{array}{l}\text { Best fit } \\
\text { identification }\end{array}$ & $\begin{array}{l}\text { Location of } \\
\text { impressions }\end{array}$ & $\begin{array}{l}\text { Number of } \\
\text { impressions }\end{array}$ \\
\hline & & & $\begin{array}{l}\text { Excavation }(2005,2006 \text { and } \\
\text { 2013) }\end{array}$ & $\begin{array}{l}\text { Panicum } \\
\text { miliaceum }\end{array}$ & & \\
\hline $13 \mathrm{a}$ & 132 sherds of vessel bottoms & Hillfort Usatovo & & $\begin{array}{l}\text { Hordeum } \\
\quad \text { vulgare }\end{array}$ & $\begin{array}{l}\text { Inner } \\
\text { surface }\end{array}$ & 1 \\
\hline $13 b$ & & Hillfort Usatovo & Fragment 11,543 & $\begin{array}{l}\text { Unidentified } \\
\text { grass }\end{array}$ & $\begin{array}{l}\text { Inner } \\
\text { surface }\end{array}$ & 1 \\
\hline $13 \mathrm{c}$ & & Hillfort Usatovo & Fragment $\sigma /$ no., p. И, square 36 & $\begin{array}{l}\text { Hordeum } \\
\text { vulgare }\end{array}$ & $\begin{array}{l}\text { Inner } \\
\text { surface }\end{array}$ & 1 \\
\hline $14 \mathrm{a}$ & 334 sherds of vessel walls & Hillfort Usatovo & Fragment 3862, 1932-1933 & $\begin{array}{l}\text { ear of } \\
\text { Hordeumvulg- } \\
\text { are }\end{array}$ & & Broken part \\
\hline $14 b$ & & Hillfort Usatovo & Fragment 3862, 1932-1933 & $\begin{array}{l}\text { Hordeum } \\
\quad \text { vulgare }\end{array}$ & & 2 \\
\hline $14 \mathrm{c}$ & & Hillfort Usatovo & $\begin{array}{l}\text { Fragment } 5656,1933, \\
\quad \text { excavation T, square } 36\end{array}$ & $\begin{array}{l}\text { Panicum } \\
\text { miliaceum }\end{array}$ & $\begin{array}{l}\text { Outside } \\
\text { surface }\end{array}$ & 1 \\
\hline $14 \mathrm{~d}$ & & Hillfort Usatovo & Fragment no. 10,103. 1956 & $\begin{array}{l}\text { Panicum } \\
\text { miliaceum }\end{array}$ & & 1 \\
\hline $14 \mathrm{e}$ & & Hillfort Usatovo & Fragment no. 5615 & $\begin{array}{l}\text { Panicum } \\
\quad \text { miliaceum }\end{array}$ & $\begin{array}{l}\text { Outside } \\
\text { surface }\end{array}$ & 1 \\
\hline $14 \mathrm{f}$ & & Hillfort Usatovo & $\begin{array}{l}\text { Fragment no. 5641, 1933, } \\
\quad \text { Squares } 35-36\end{array}$ & & $\begin{array}{l}\text { Outside } \\
\text { surface }\end{array}$ & 1 \\
\hline 15 & 91 sherds & Hillfort Usatovo & & & & \\
\hline $16 \mathrm{a}$ & 167 sherds of thin vessel walls & Hillfort Usatovo & Fragment no. 10,770 & $\begin{array}{l}\text { Unidentified } \\
\text { grass }\end{array}$ & & 1 \\
\hline $16 b$ & & Hillfort Usatovo & $\begin{array}{l}\text { Fragment no. 2656, excavation } \\
\quad \text { S, square } 116,1932\end{array}$ & $\begin{array}{l}\text { Unidentified } \\
\text { grass }\end{array}$ & & 1 \\
\hline $17 \mathrm{a}$ & $\begin{array}{l}243 \text { sherds of large thick walled vessels } \\
\text { bottoms }\end{array}$ & Hillfort Usatovo & Fragment no. 731(?) & $\begin{array}{l}\text { Unidentified } \\
\text { grass }\end{array}$ & & 1 \\
\hline $17 b$ & & Hillfort Usatovo & $\begin{array}{l}\text { Fragment no. } 6183 \text {, excavation } \\
\text { 1, square } 29, \text { loam horizon, } \\
1933\end{array}$ & $\begin{array}{l}\text { Hordeum } \\
\text { vulgare }\end{array}$ & & 1 \\
\hline $17 \mathrm{c}$ & & Hillfort Usatovo & $\begin{array}{l}\text { Fragment no. 9360, excavation } \\
\text { И, } 1940\end{array}$ & $\begin{array}{l}\text { Panicum } \\
\quad \text { miliaceum }\end{array}$ & $\begin{array}{l}\text { Outside } \\
\quad \text { surface } \\
\text { (?) }\end{array}$ & 1 \\
\hline $18 \mathrm{a}$ & 327 sherds of large undecorated vessels & Hillfort Usatovo & $\begin{array}{l}\text { Fragment no. } 2179 \text {, excavation } \\
\quad 8 \text {, square } 120,1932\end{array}$ & $\begin{array}{l}\text { Triticum } \\
\quad \text { dicoccon }\end{array}$ & & 1 \\
\hline $18 \mathrm{~b}$ & & Hillfort Usatovo & Fragment no. 2171 & $\begin{array}{l}\text { 'Spikelet fork' of } \\
\text { Triticum } \\
\text { dicoccon }\end{array}$ & & 1 \\
\hline $18 \mathrm{c}$ & & Hillfort Usatovo & $\begin{array}{l}\text { Fragment no. 2122, excavation } \\
\quad \text { S, } 1932\end{array}$ & $\begin{array}{l}\text { Panicum } \\
\quad \text { miliaceum }\end{array}$ & & 1 \\
\hline $18 \mathrm{~d}$ & & Hillfort Usatovo & Fragment no. 2026, 1932-1933 & $\begin{array}{l}\text { Triticum } \\
\quad \text { aestivums.l. }\end{array}$ & & 1 \\
\hline $18 \mathrm{e}$ & & Hillfort Usatovo & $\begin{array}{l}\text { Fragment no. 9120, excavation } \\
\quad \mathrm{S}, 1932\end{array}$ & $\begin{array}{l}\text { Hordeum } \\
\text { vulgare }\end{array}$ & & 1 \\
\hline $18 \mathrm{f}$ & & Hillfort Usatovo & Fragment no. 8806 & $\begin{array}{l}\text { Panicum } \\
\quad \text { miliaceum }\end{array}$ & & 1 \\
\hline $18 \mathrm{~g}$ & & Hillfort Usatovo & $\begin{array}{l}\text { Fragment no. } 8233 \text {, squares } \\
\quad 35-36,1933\end{array}$ & $\begin{array}{l}\text { Triticum } \\
\quad \text { monococcum }\end{array}$ & & 1 \\
\hline $18 \mathrm{~h}$ & & Hillfort Usatovo & $\begin{array}{l}\text { Fragment no. } 8710 \text {, excavation } \\
\text { И, } 1940\end{array}$ & $\begin{array}{l}\text { Panicum } \\
\quad \text { miliaceum }\end{array}$ & & 1 \\
\hline $18 \mathrm{i}$ & & Hillfort Usatovo & Fragment no. 8860 & Pisum sp. & & 1 \\
\hline $19 \mathrm{a}$ & 106 sherds & Unspecified & $\begin{array}{l}\text { Fragment no. } 9627 \text {, excavation } \\
\text { T, squares } 29-35,1933\end{array}$ & $\begin{array}{l}\text { Hordeum } \\
\text { vulgare }\end{array}$ & & 1 \\
\hline $19 b$ & & & $\begin{array}{l}\text { Fragment no. } 8410 \text {, excavation } \\
\quad \mathrm{T}, 1933\end{array}$ & $\begin{array}{l}\text { Panicum } \\
\text { miliaceum }\end{array}$ & $\begin{array}{l}\text { Vessel } \\
\text { bottom }\end{array}$ & 1 \\
\hline $19 \mathrm{c}$ & & & Fragment no. 8409 & Pisum sp. & & 1 \\
\hline $19 \mathrm{~d}$ & & & $\begin{array}{l}\text { Fragment no. } 5145 \text {, excavation } \\
\quad \mathrm{T} \text {, square } 29,1933\end{array}$ & Cannabis sp. & & 1 \\
\hline $19 \mathrm{e}$ & & & $\begin{array}{l}\text { Fragment no. } 7869 \text {, excavation } \\
\quad \text { B, square } 12,1940\end{array}$ & $\begin{array}{l}\text { Panicum } \\
\quad \text { miliaceum }\end{array}$ & & 1 \\
\hline $19 \mathrm{f}$ & & & $\begin{array}{l}\text { Fragment no. } 6432 \text {, excavation } \\
\quad \text { S, square } 39,1932\end{array}$ & $\begin{array}{l}\text { Panicum } \\
\quad \text { miliaceum }\end{array}$ & & 1 \\
\hline $20 \mathrm{a}$ & 122 sherds of vessel walls & Hillfort Usatovo & & Cornus mas & & 1 \\
\hline
\end{tabular}


Table 1 (continued)

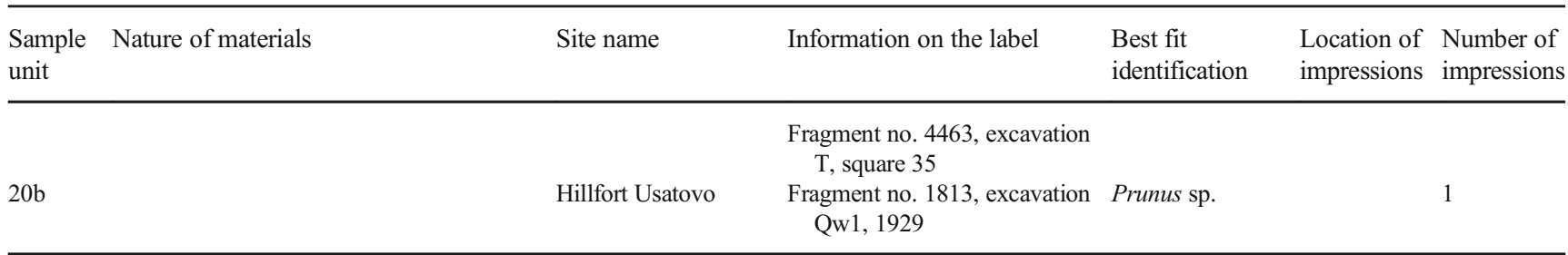

\section{Results of optical microscope examination}

We examined approximately 2720 ceramic sherds from hillfort and burial contexts and 21 anthropomorphic figurines (or fragments of them) from burial context of Usatovo site; 456 ceramic fragments and 2 boxes of clay daub from hillfort context of Mayaki site.

The findings of crop impressions, organised by archival storage unit, are recorded in Tables 1 and 2. Some of the impressions were found on the same fragments. In most cases, the findings on pottery fragments are individual impressions, whereas the multiple impressions tend to be found on clay daubs. They retain a significant amount of morphological details including scales and glumes, fragments of culms, parts of leaves, grains, seeds, nuts, "triplets" of naked barley (Hordeum vulgare var.nudum), and also "spikelet forks" (the internode fragments with attached glume bases) of einkorn and emmer wheat (Triticum monococcum and Triticum dicoccum).

Among the 14 pieces of millet impressions, 9 come from hillfort Usatovo, 2 from hillfort Mayaki and another 3 from unspecified sites. Thirteen pieces of them are found in pottery sherds and one piece in clay daubs. The impressions that were often found on Usatovo

Table 2 Summaries of plant impression records in Usatovo materials

\begin{tabular}{lc}
\hline Best fit taxa & Number of findings of each species \\
\hline Hordeum vulgare & 28 \\
Hordeum vulgarevar.coeleste & 1 \\
Panicum miliaceum & 14 \\
Triticum dicoccon & 5 \\
Cannabis sp. & 3 \\
Triticum aestivum & 2 \\
Triticum monococcum & 1 \\
Pisum sativum & 2 \\
Cornus mas & 1 \\
Prunus sp. & 2 \\
Poa sp. & 2 \\
Bromus sp. & 1 \\
Unidentified & 1 \\
Unidentified grass & 9 \\
\hline
\end{tabular}

figurines such as those in Fig. 2 might be more plausibly explained by impressions of hollow stems rather than of cereal grains. No crop impressions have been found in the current study on the anthropomorphic figurines.

\section{Result of SEM examination}

Casts were prepared from the 14 pieces of potential millet impressions (multiple casts were often made of the same impressions in case of insufficient capture or damage during transportation). These casts were sent from Ukraine to Cambridge. Since many of the casts lost details during their transportation, the seven best plasticine casts were further examined and photographed using SEM. They were then compared to SEM images of simulated impressions of Panicum miliaceum.

In simulated Panicum miliaceum impressions, we are able to observe such characteristics as grain size, the two ends being distinctly shaped, rachises attached to the grain and moreover, the absence of surface patterns on lemma and palea (Fig. 3). In particular, the latter feature is most distinctive from that of Setaria italica (Fig. 4). In the case of dehusked grain impressions (Fig. 3), instead of husk features, details of the hilum are clearly visible, implying that if the dorsal side is impressed, then we can expect to see the shape and length of embryo as well.

The SEM images of our casts from Ukraine (Figs. 5 and 6) show that the sizes are slightly larger than those of simulated impressions but are still within the size

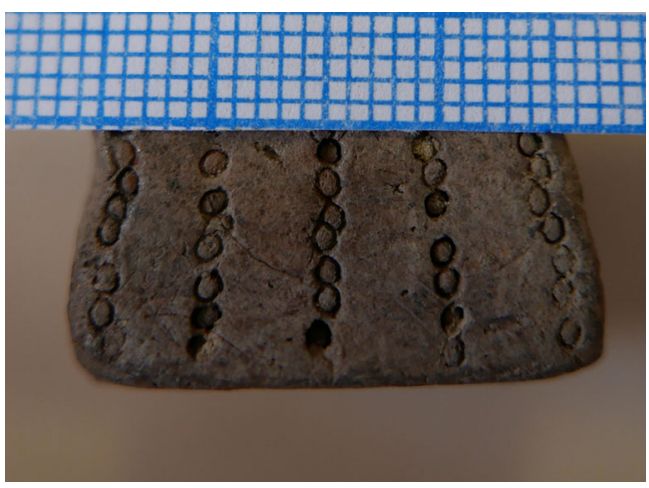

Fig. 2 Impressions of hollow stems in Usatovo figurines 

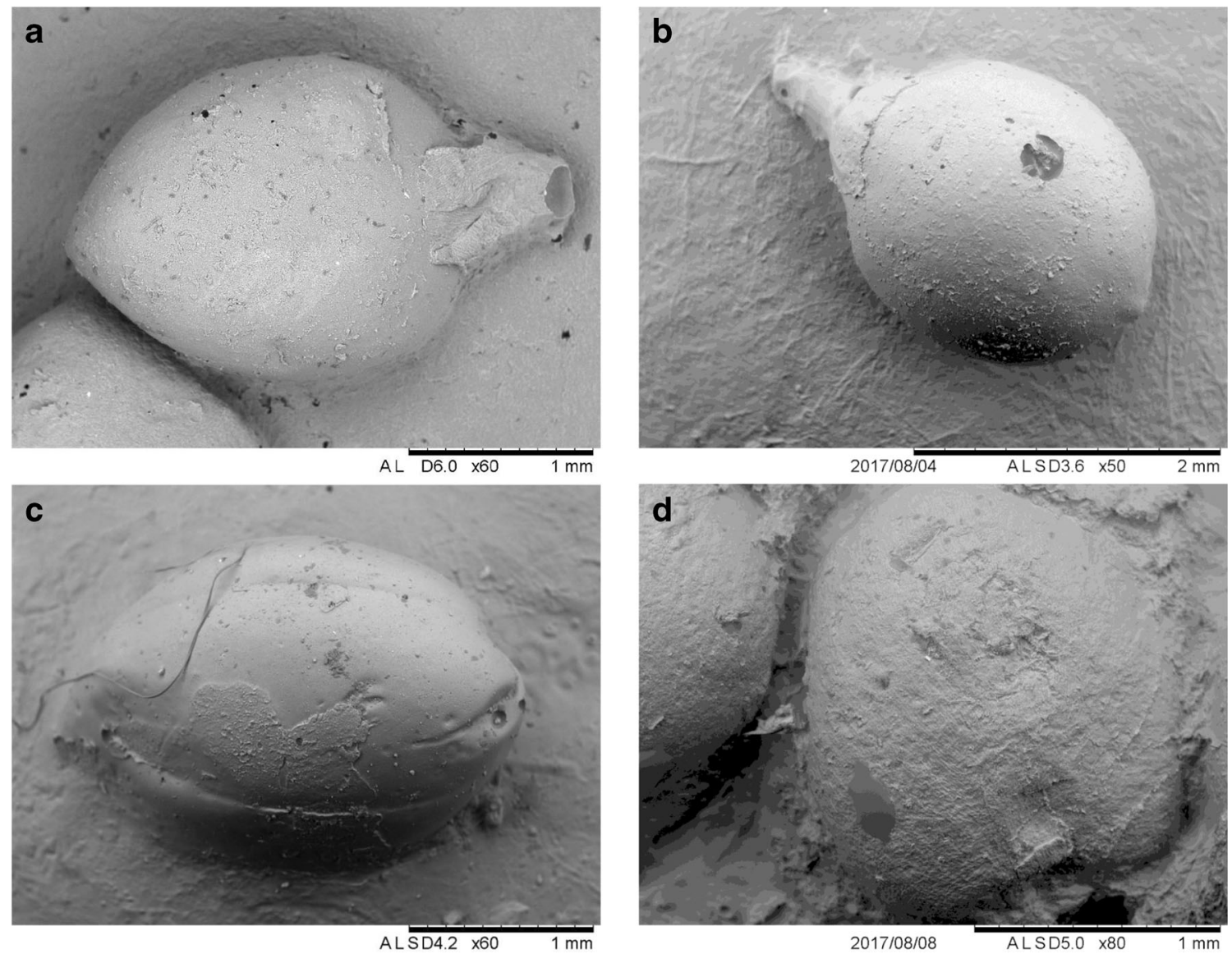

Fig. 3 SEM images of silicone casts of simulated impressions of Panicum miliaceum grain (2018)

range of Panicum miliaceum grain. Measurements of simulated millet impressions and our Usatovo samples are summarised in Table 3.

Meanwhile, surface patterns are absent. Rachises are not seen in any of the images. The indicative acute end of Panicum miliaceum grain is not always seen either. Instead, our samples in images A, C, D, F, and G have a more or less blunt or roundish shape.

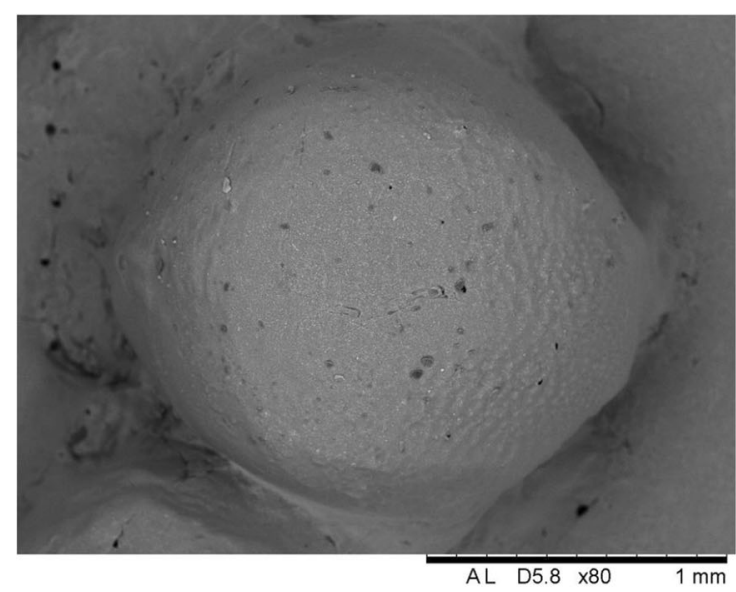

Fig. 4 SEM images of silicone casts of simulated impressions of Setaria italica grain (2018)

\section{Discussion}

Our visual identification results (Table 1) would suggest that the three predominant cereals in Usatovo materials consist of hulled wheat (both emmer wheat and einkorn wheat), hulled barley and broomcorn millet. Meanwhile, there are also findings of naked wheat, naked barley, peas and nutlets of hemp, etc. Our results are consistent with those of Kuzminova and

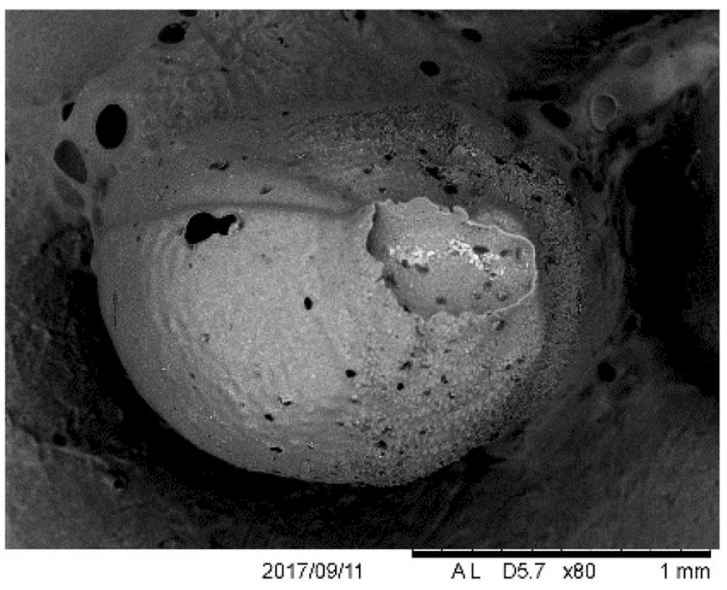



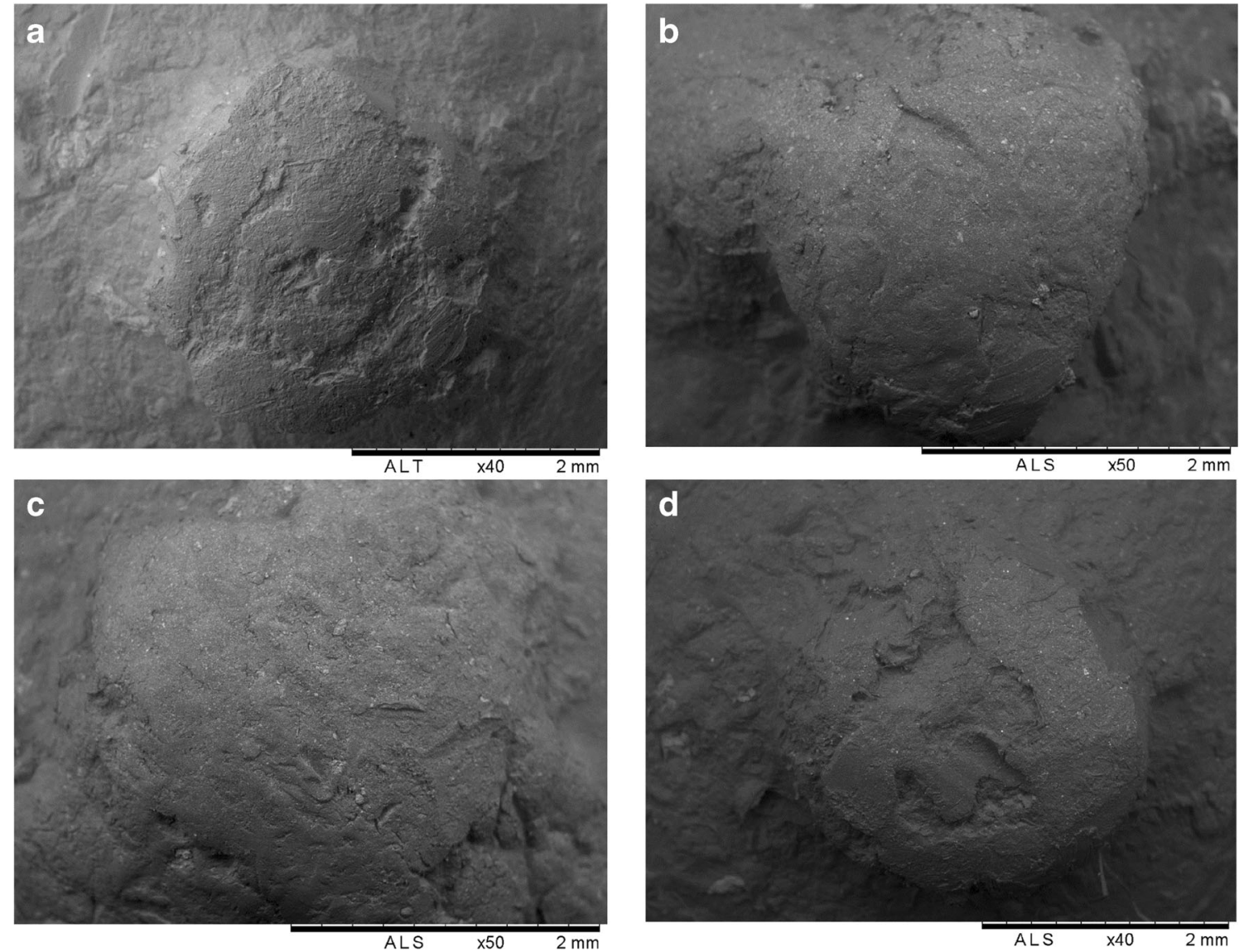

Fig. 5 SEM images of plasticine casts of our Usatovo samples. A is found in clay daub from ditch at hillfort Mayaki (2c in Table 1), no identification suggested. $\mathrm{b}$ is found in vessel wall from hillfort Usatovo (6 in Table 1), no identification suggested. $\mathrm{c}$ is found in sherd bottom from

hillfort Usatovo (9c in Table 1), no identification suggested. $d$ is found in vessel wall from hillfort Usatovo (14e in Table 1), identified as cf. Panicum miliaceum

Petrenko (1989). However, contra the latter (ibid. p.119), few of these impressions are found on anthropomorphic figurines but instead on pottery sherds and clay daubs. Given the small number of crop impressions encountered, we infer that crops were added along with straws and weedy species as vegetative additives.

\section{Robustness of millet impression identification}

Among all crop impressions, the findings of potential millet imprints are of particular interest.

There are different identification features for millet impressions of untreated and dehusked grain. On the one hand, in simulated impressions of husked millet grain, this includes size, the shape of grain end (one is acute and the other blunt) and absence of surface patterns on lemma and palea. The absence of husk surface pattern is significant in distinguishing from other millet species such as Setaria italica. Meanwhile, rachises are seen in two images of our simulated millet impressions. This is consistent with Bakels' findings of broomcorn millet impressions with rachises on Bronze Age vessels dating to around $2000 \mathrm{BC}$ (Bakels 2003).

In the case of dehusked grain impression, the identifying features: shape of grain, shape and location of hilum and shape and length of embryo. Hilum and embryo can be clearly discerned in the impression, although one may expect to see only one of the two in each case.

From our visual re-examination of Usatovo materials (around 3500-2950 BC), we have been able to confirm that one of the commonest forms of impression void matches the dimensions of Panicum miliaceum grain. The SEM examination of our Usatovo casts offers more details about the voids. Apart from a slightly larger dimension than those of simulated millet impressions, we can also see that some voids are roundish while others are elliptical. The acute end of Panicum miliaceum is not always seen. The absence of distinctive scutellum details would indicate that most of the impressions had been made from husked grain. The one exception is the one in Image D (Fig. 5), on which the shape of an embryo may possibly be discerned. Surface patterns is absent from all specimens, which may not necessarily confirm Panicum miliaceum grain but helps to exclude Setaria sp. and also Echinochloa sp., whose husks carry distinctive patterns (An 2018). Moreover, rachises are not seen in any of the images 

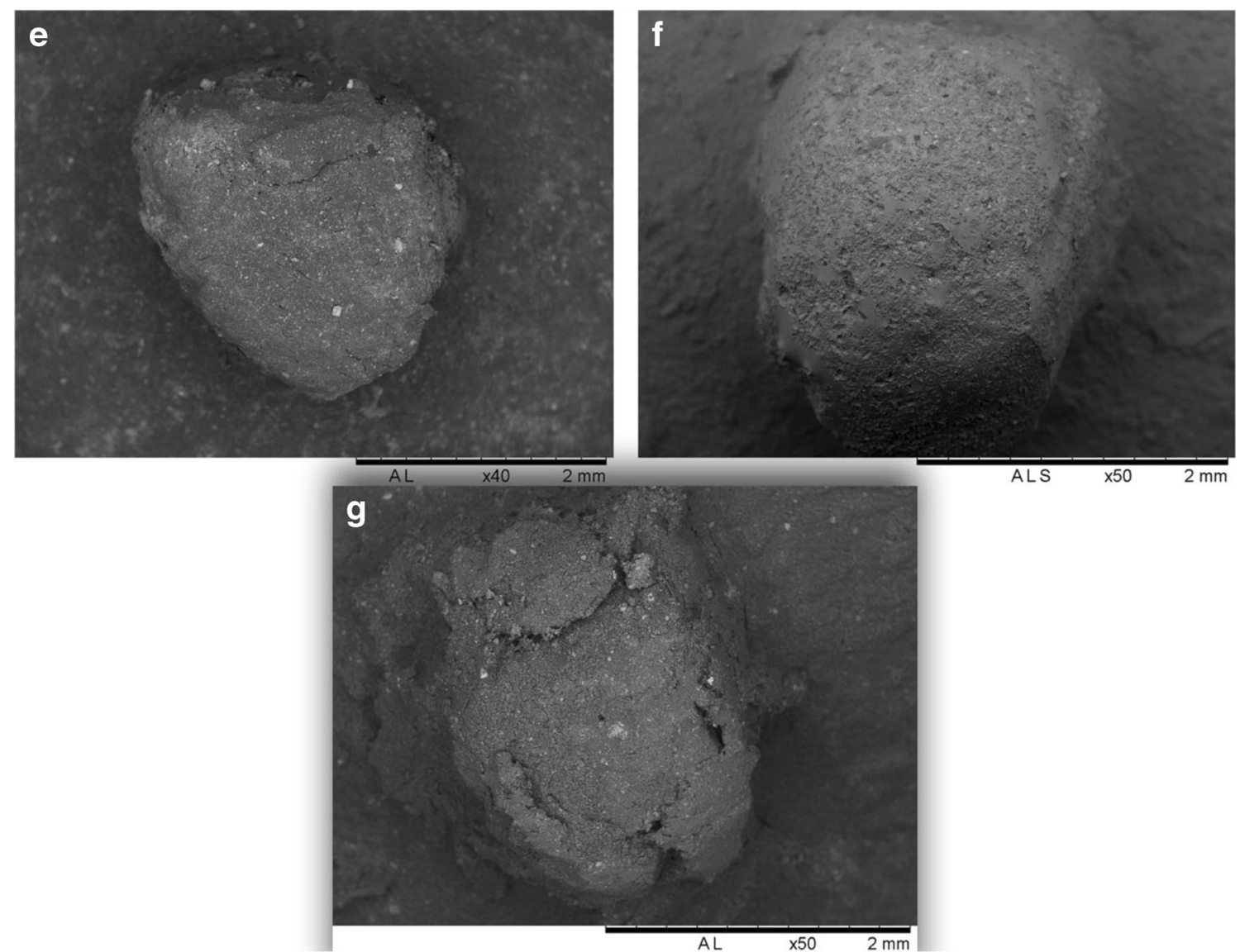

Fig. 6 SEM images of plasticine casts of our Usatovo samples. e is found in vessel bottom from hillfort Usatovo (17c in Table 1), identified as cf. Lathyrus sp. $\mathrm{f}$ is found in large undecorated vessels from hillfort Usatovo

while spikelets are visible in most images, which might indicate that the impressions are made from brittle rachis forms. In the case of dehusked grain impression in Image D, if the embryo details are substantiated, then it does not eliminate the possibility of dehusked Panicum miliaceum grain. There is insufficient evidence of shape to clarify the species.

\section{Reliability of Usatovo chronology}

As our findings leave open the possibility that some impressions may be millet, it is relevant to return to the issue (18c in Table 1), no identification suggested. $\mathrm{g}$ is also found in large undecorated vessels from hill fort Usatovo (18f in Table 1), identified as cf. Trifolium sp.

of the chronology of Usatovo culture. As indicated above, the conventionally accepted date range for Usatovo culture is 3500-2900 BC. If both this date range, and the identification of any of the millet impressions proved to be secure, then that would favour a significantly early date for Asian millet movement across Eurasia, unparalleled by other evidence. If, however, the later carbon dates which had been excluded as outliers by Petrenko and Kaiser (2011) proved instead to be robust and indicated a much longer duration for Usatovo culture, then the mille impressions might theoretically fall into the second

Table 3 Measurements (in centimetres) of both simulated millet impressions and our usatovo samples

Modern simulated Panicum miliaceum impression (Fig. 3)

Husked grain

Grain A: length 2.2, width 1.5

Grain B: length 2.3, width 1.9

Grain C: length 2.5 , width 1.7

Dehusked grain
Grain D: length 1.7, width 1.4
Usatovo cf. millet impression (Figs. 5 and 6)

Grain A: length 2.9 (incomplete), width 2.6 (incomplete)

Grain B: length 2.7 (incomplete), width 2.5

Grain C: length 2.7, Width: 2.5

Grain E: length 2.8 (incomplete), width 2.6

Grain F: length 2.7 (incomplete), width 2.2

Grain G: length 2.5 (incomplete), width 2.0

Grain D: length 2.5 (incomplete), width 2.3 (incomplete) 
millennium $\mathrm{BC}$, in line with a larger body of transEurasian evidence.

\section{Conclusion}

Our re-examination of Usatovo millet impressions contributes to the ongoing debate on the robustness of pre-2000 BC millet findings in Europe. The current study shows that one of the commonest forms of impression void matches the dimensions of Panicum miliaceum grains. While sufficient recorded surface feature to allow a secure identification remain elusive, plausible voids have been confirmed in ceramics from the west assumed to predate the second millennium BC.

Turning from archaeological evidence to simulated impressions, we have demonstrated that all diagnostic features of millet taxa are in principle observable through SEM in the case of actual millet impressions. These features include one acute end, the other blunt, and absence of surface patterns on lemma and palea, or in the case of dehusked grain, the shape and length of embryo and the shape and location of hilum. In the SEM images of our Ukraine samples, apart from dimensions, we were only able to observe the absence of surface patterns in impressions of possible husked grain and potential embryo details in one impression of dehusked grain. Whether or not any of these do relate to Panicum miliaceum, the absence of patterning allows us to exclude both Setaria sp. and Echinochloa sp.

Our re-examination of Usatovo millet impressions and Usatovo chronology permits more than one narrative. If both Usatovo millet impressions and Usatovo chronology are substantiated, this might indicate either a very early contact between Eurasian communities, or alternatively a domestication event in the west, although the latter is not supported by genetic evidence (Hunt et al. 2018). If millet impressions are substantiated while Usatovo chronology is adjusted to accommodate the later dates excluded by Petrenko and Kaiser (2011), the time gap between Usatovo millet impressions and other early direct dated millet findings in the west of Altai might disappear. There remains the third possibility, that some common but hitherto unidentified item of broadly similar dimensions is responsible for the 'millet' impressions.

In future studies, we would urge researchers to be explicit about the range of features they observe during their examination of potential millet impressions. Visible features one can expect include

1. Shape of caryopsis: one end is acute while the other is blunt

2. Surface pattern is absent on both lemma and palea

3. The embryo is widely ovate with the ratio of length: width close to 1; the length of it is between 50 and $70 \%$ of the grain
4. The hilum is round and is located close (but not attached) to the basal end

Whatever the resolution of the very early millet-shaped impressions from the west of the Altai, that resolution will have important implications for understanding of the prehistory of trans-Eurasian contact. Meanwhile, flotation should be encouraged in sites with early millet-shaped impression findings so as to answer the question once and for all.

Acknowledgements The paper is part of TA's doctoral thesis carried out under the supervision of MJ at Department of Archaeology, University of Cambridge. We are grateful to Dr. Giedre Motuzaitè-Matuzevičiūte for putting the co-authors into contact. We thank Dr. Vlad Petrenko, Usatovo specialist from Odessa Archaeological Museum for permission and facilities to work there. We thank Mr. Dmitriy Yanov from Odessa Archaeological Museum for the incredible amount of interpretation and translation work. We thank Dr. Emma Lightfoot and Miss Huiru Lian for helping prepare the figures. TA is grateful to McDonald institute for Archaeological Research (Cambridge) and also 2016 Andrew Sherratt Grant (from Department of Archaeology, University of Sheffield) for travel support.

Open Access This article is distributed under the terms of the Creative Commons Attribution 4.0 International License (http:// creativecommons.org/licenses/by/4.0/), which permits unrestricted use, distribution, and reproduction in any medium, provided you give appropriate credit to the original author(s) and the source, provide a link to the Creative Commons license, and indicate if changes were made.

Publisher's Note Springer Nature remains neutral with regard to jurisdictional claims in published maps and institutional affiliations.

\section{References}

An T (2018) Re-visiting the co-relation of movement of Chinese millet and painted pottery before the 2nd millennium BC. Unpublished $\mathrm{PhD}$ thesis, University of Cambridge

Bakels C (2003) Report concerning the contents of a ceramic vessel found in the 'white room' of the Gonur Temenos, Merv Oasis, Turkmenistan. Electron J Vedic Stud 9(1c)

Diachenko A, Harper TK (2016) The absolute chronology of late Tripolye sites: a regional approach. Sprawozdania Archeologiczne 68:81-105

Fuller DQ (2006) A millet atlas: some identification guidance. Unpublished teaching materials, University College London

Fuller DQ, Macdonald K (2007) Early domesticated pearl millet in Dhar Nema (Mauritania): evidence of crop processing waste as ceramic temper. In: Cappers R (ed) Fields of change: progress in African Archaeobotany. Barkhuis Publishing \& Groningen University, Groningen

Hunt HV, Vander LM, Liu XY, Motuzaite-Matuzeviciute G, Colledge S, Jones MK (2008) Millets across Eurasia: chronology and context of early records of the genera Panicum and Setaria from archaeological sites in the Old World. Veget Hist Archaeobot 17:S5-S18

Hunt H, Rudzinski A, Jiang H, Wang R, Han Y, Thomas M, Gones M (2018) Genetic evidence for a western Chinese origin of Broomcorn Millet (Panicum miliaceum). The Holocene 28(12):1968-1978 
Ivanova M (2013) The Black Sea and the early civilisations of Europe, the Near East and Asia. Cambridge University Press, Cambridge

Kuzminova NN (1990) Paleoethnobotanical and palynological analysis of the materials from the burial mounds of the Lower Dnestr region. In: E. V., Y. (ed.) The burial mounds of Eneolithic - Bronze age in the Lower Dnestr region. Știința, Chișinău

Kuzminova NN (1991) Crops and weeds in the Tripolye culture sites in Moldavia: Palaeoethnobotany and archaeology. In: Hijnalová E (ed) International Work Group for Palaeoethnobotany, the 8th Symposium, 1991 Nitra. Archaeological Institute of the Slovak Academy of Sciences, Nitra, pp 199-201

Kuzminova NN, Petrenko VG (1989) Kulturnye rasteniya na zapade Stepnogo Prichernomorya v seredine 3-2 tis. do n. e. (po dannym paleobotaniki). In: Tolochko PP (ed) Problemu Drevnei Istorii i Arkheologii Ukrainskoi SSR. Naukova Dumb, Kiev

Magid A (1989) Plant domestication in the Middle Nile basin: an archaeoethnobotanical case study. British Archaeological Reports, Oxford

Mallory JP, Adams DQ (1997) Encyclopedia of Indo-European culture. Fitzroy Dearborn, London

Motuzaite-Matuzeviciute G (2012) Experimental approaches to understanding variation in grain size in Panicum miliaceum (broomcorn millet) and its relevance for interpreting archaeobotanical assemblages. Veget Hist Archaeobot 21(1):69-77

Motuzaite-Matuzeviciute G, Staff R, Hunt HV, Liu XY (2013) Small sample graphite radiocarbon dating forces re-evaluation of the early chronology of broomcorn millet (Panicum miliaceum) in Europe. Antiquity 87:1073-1085
Nesbitt M, Summers G (1988) Some recent discoveries of millet (Panicum miliaceum L. and Setaria italica (L.) P. Beauv.) at excavations in Turkey and Iran. Anatol Stud 38:85-97

Petrenko V, Kaiser E (2011) Kompleksnyj pamjatnik Majaki: Novye Izotopnye Daty I Voprosy Hronologii Nalichnyh Kul'tur. In: Bruyako IV (ed) Materiali Po Arkheologii Severnogo Prichernomor'ya. Pechatniy Dom, Odessa

Renfrew JW (1973) Palaeoethnobotany: the prehistoric food plants of the near East and Europe. Methuen \& Co. Ltd, London

Stevens C, Murray C, Roberts R, Lucas L, Silva F, Fuller DQ (2016) Between China and South Asia: a middle Asian corridor of crop dispersal and agricultural innovation in the Bronze Age. The Holocene 26:1541-1555

Weninger K, Harper T (2015) The geographic corridor for rapid climate change in Southeast Europe and Ukraine. In: Hansen S, Raczky P, Anders A, Reingruber A (eds) Neolithic and Copper Age between the Carpathians and the Aegean Sea. Deutsches Archäologisches Institut, Berlin

Yanushevich ZV (1976) Kulturnie Rastenia Yugo-Zapada SSR Po Paleobotanicheskim Issledovaniyam (culticated plants of southwest USSR from Palaeoethnobotanical researches). Kișinev

Yanushevich ZY (1978) Paleobotanicheskie Issledovaniya v Dnestrovsko-Prutskom Mezdurechye Issledovaniya Botaničeskogo sada Akademii Nauk Moldavskoj SSR (1947-1977). Kișinev

Yanushevich ZY (1989) Agricultural evolution north of the Black Sea from the Neolithic to the Iron Age. In: Harris DRGCH (ed) Foraging and farming: evolution of plant exploitation. Routledge, London 